\title{
Impact of Covid-19 Semi-lockdown on Sports and Physical Activity Behaviors of Cameroonian Elite Volleyball Players: A Cross-sectional Study
}

Wiliam Richard Guessogo ${ }^{1}$, Elysée Claude Bika-Lele², William Mban-Bian ${ }^{3}$, Audrey Rose Deborah Mandjek ${ }^{3}$, Abdou Temfemo ${ }^{4}$, Samuel Honore Mandengue ${ }^{5}$, Peguy Brice Assomo-Ndemba ${ }^{6}$

${ }^{1} \mathrm{PhD}$, Senior Lecturer, National Institute of Youth and Sports, Yaounde, Cameroon

${ }^{2} \mathrm{PhD}$, Lecturer, Exercise and Sport Physiology Unit, University of Douala, Douala, Cameroon

${ }^{3}$ MSc, National Institute of Youth and Sports, Yaounde, Cameroon

${ }^{4} \mathrm{PhD}$, Associate Professor, Faculty of Medicine and Pharmaceutical Sciences, University of Douala, Douala, Cameroon

${ }^{5} \mathrm{PhD}$, Full Professor, Exercise and Sport Physiology Unit, University of Douala, Douala, Cameroon

${ }^{6} \mathrm{PhD}$, Associate Professor, Faculty of Medicine and Biomedical Sciences, University of Yaounde 1, Yaounde, Cameroon

Type of article: Original

\begin{abstract}
Background: The sport domain experienced major disruptions due to the Covid-19 pandemic.

Objective: To determine the effects of Covid-19 semi-lockdown on elite volleyball players in Cameroon.

Methods: From June 29 to July 30, 2020, 111 volleyball players completed a self-administered questionnaire adapted from a physical activity maintenance questionnaire, to collect anthropometric parameters before and after relaxation, physical activity maintenance, number and type of training sessions, and opinion on physical capacities during and after semi-lockdown. Data were analyzed by IBMC SPSS $\odot$ Statistics version 20. Comparisons were made by independent-samples t-test for quantitative variables and Pearson Chi-square goodness of fit test for qualitative variables. A p-value of $<0.05$ was considered statistically significant.

Results: Around $70.3 \%$ of the players experienced a body mass index (BMI) increase, $1.8 \%$ kept the same, and $27.9 \%$ decreased their BMI. About $82 \%$ of volleyball players continued training, without any sex difference ( $\mathrm{p}=0.91$ ). Meanwhile, $72.5 \%$ trained at home, $68.1 \%$ individually, and $74.7 \%$ by self-motivation, with more males training than females $(\mathrm{p}=0.004)$. Almost $33.3 \%$ increased individual training sessions, $71.4 \%$ reduced group training sessions, and $29.4 \%$ reduced training sessions with a coach. About $60.4 \%$ received personalized training programs, $65.0 \%$ preferred physical training, and $21.2 \%$ completed aerobic exercises. Athletes thought that the semi-lockdown induced strength loss (43.1\%), speed loss $(55 \%)$, and endurance loss (78\%). After the first training session, the coach qualified the physical capacities as average (73.2\%).

Conclusion: Practice of regular physical activity should be encouraged among athletes during the pandemic period to ensure a safe return to sports.
\end{abstract}

Keywords: Covid-19, Physical activity behaviors, Semi-lockdown, Elite volleyball players, Cameroon, Sport

\author{
Abbreviations / Acronyms: \\ BMI: Body Mass Index. \\ UEFA: Union of European Football Associations.
}

\section{Corresponding author:}

Dr. Wiliam Richard Guessogo, National Institute of Youth and Sports, Yaounde, Cameroon.

Tel: +237.698134943, E-mail: guessowiliam@yahoo.fr

Received: November 30. 2020, Accepted: February 02, 2021, Published: March 2021

Ethics approval: National Institute of Youth and Sports, Yaounde, Cameroon (Ref: $\mathrm{N}^{\circ}$ 008/DA/INJS).

(C) 2021 The Authors. This is an open access article under the terms of the Creative Commons Attribution-NonCommercialNoDerivs License, which permits use and distribution in any medium, provided the original work is properly cited, the use is non-commercial and no modifications or adaptations are made. 


\section{Introduction}

\subsection{Background and study logic}

Since December 2019, China (Wuhan) has been affected by a new virus from the coronavirus family, SARS-COV2, responsible for the disease called Covid-19 (1-4). Covid-19 spread rapidly across the world and became the largest pandemic the world has known. In order to limit the spread of the virus, health authorities have issued safety recommendations and the governments of many countries adopted measures that the public was advised to observe. These measures included travel restrictions, social isolation at home, school closures, etc. (5). The Cameroonian Public Health Ministry declared that there were 17,255 positive cases and 387 deaths in July 2020. The barrier measures decreed by governments affected socio-economic activities (6), as well as the physical activity behavior of the population. This can lead to health problems associated with inactivity $(7,8)$. Therefore, it has been recommended to continue physical activity at home during this period of confinement (9-11). The sports milieu was also affected all over the world, with a total interruption or postponement of sports activities and championships since early March 2020, such as the Olympic Games, the UEFA Champions League, the African Cup of Nations, and the African Nations Championship $(12,13)$. In Cameroon, following the introduction of the barrier measures enacted on March 17, 2020 by the Cameroonian Government, the sports federations also suspended their activities. This is the specific case of the Cameroonian volleyball federation, whose championship was just beginning. This public health situation forced players and coaches to adopt new behaviors to maintain the level of fitness already acquired. Several studies have assessed the impact of the Covid-19 pandemic on the sport. One study carried out among South African athletes showed that this pandemic has affected over 14 sports disciplines, including volleyball (14). In Cameroon, where the pandemic also led to a change in sports programs, a recent study by Guessogo et al. (15) focusing on basketball players revealed that the semi-confinement due to the Covid-19 pandemic has significantly affected the behavior and attitude of players. To our knowledge, there are no dedicated studies conducted so far on Cameroonian elite volleyball players.

\subsection{Objective}

The objective of this work was to determine the effects of Covid-19 semi-lockdown among elite volleyball players in Cameroon, in 2020.

\section{Material and Methods}

\subsection{Study design and time period}

This cross-sectional study was carried out in the period from June 29, 2020 (resumption of normal professional and academic activities) to July 30, 2020, in the city of Yaounde (Cameroon). The survey was carried out among volleyball players, based on a questionnaire adapted from a validated physical activity maintenance questionnaire (16). Information collected included anthropometric parameters (height, weight, and body mass index), maintenance of physical activity, number of training sessions, type of training session, and opinion on physical capacities.

\subsection{Sampling method and participants}

Because of the barrier measures introduced in Cameroon, such as restriction of movement, we used a convenience non-probability sampling method. The sample size was calculated using Raosoft calculator with a 95\% confidence level and a maximum error of 5\%. The total population consisted of 111 volleyball players so that the required response rate would be $50 \%$ (recommended). They were recruited after signing an informed consent form. Due to the relaxation of the barrier measures enacted by the government of the Republic of Cameroon, on the one hand, and the provision by the administration of the Cameroon Volleyball Federation of the telephone file of players from the different teams in Yaounde, on the other hand, these athletes were approached by the principal investigator. Elite sportsmen affiliated with the Cameroon Volleyball Federation, over 18 years old and residing in the city of Yaounde, were included in the study.

\subsection{Measures and instruments}

\subsubsection{Anthropometric parameters}

The anthropometric parameters were determined in compliance with the barrier measures decreed by the government and health authorities (social distancing, wearing a mask, regular hand washing, and use of hydroalcoholic gel). The weight of the athletes was measured using a TANITA BC 532 brand electronic scale (Tokyo, Japan) placed on a hard and flat surface, calibrated before measurement, while the weight before the introduction of barrier measures was estimated and reported by the players themselves. The heights were measured using a Seca brand measuring rod (Hamburg, Germany). The body mass index (BMI) was calculated by dividing the weight (in kilograms) by the square of the height (in meters squared). 


\subsubsection{Questionnaire on maintenance of physical activities}

This instrument was adapted from a validated questionnaire on the maintenance of activities (16). For the reliability of the questionnaire, content validity was used to establish the internal validity of the questionnaire. Nevertheless, it was revised by an expert panel with the participation of university professors not involved in the project, who approved the final version of the questionnaire. The administration of the questionnaire took place during a meeting with the athletes who answered directly. This self-administered instrument included the maintenance of physical activities, the number of training sessions per week (alone, in a group, and/or in the presence of a trainer), the measures taken to compensate for the lack of group training, the type of training session (physical and/or technical), the player's personal opinion on their physical capacities (decreased, maintained, or improved), and the qualification of the physical capacities of the players by the coach (poor, medium, good).

\subsection{Data analysis}

Quantitative variables were presented as mean \pm standard deviation (SD) while qualitative variables were presented as frequencies and percentages. The quantitative variables were compared between men and women using the independent samples t-test and the qualitative variables using the Pearson Chi-square goodness of fit test. As items were single or multiple-choice, the proportions do not add up to $100 \%$ for the questions with multiple responses. All

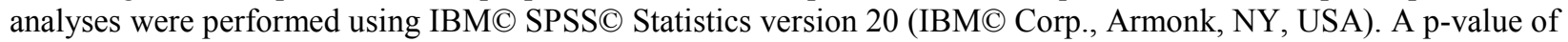
$<0.05$ was considered statistically significant.

\subsection{Ethical consideration}

The survey was approved by the Deputy Director in charge of Studies and Research of the National Institute of Youth and Sports, Yaounde, Cameroon ( $\mathrm{N}^{\circ}$ 008/DA/INJS). All participants were informed of the research procedures, which conformed to the ethical standards of the Declaration of Helsinki revised in 1989, before giving their written consent to join the study. Participants were assured that the surveys would be anonymous and that the data would be kept confidential.

\section{Results}

Table 1 presents the anthropometric characteristics of the participants. Out of a total of 111 questionnaires distributed, the mean age of respondents was $22 \pm 6$ years, $(44.1 \%$ under 20 years old, $42.3 \%$ from 20 to 30 years old, and $13.5 \%$ over 30 years old), with a significant difference depending on gender $(\mathrm{p}<0.0001)$. There were $86.5 \%$ students and $13.5 \%$ workers with a significant gender-wise difference $(\mathrm{p}<0.0001)$. The players were junior $(28.8 \%)$ and senior $(71.2 \%)$, which included gender-related differences $(\mathrm{p}=0.004)$. Regarding BMI, no significant sex difference existed in the mean value before $(\mathrm{p}=0.761)$ and after $(\mathrm{p}=0.711)$ semi-lockdown. A total of $70.3 \%$ of the players experienced a BMI increase, $1.8 \%$ kept the same BMI, and 27.9\% decreased their BMI. No significant BMI variation was noted based on gender $(\mathrm{p}=0.657)$.

Table 1. Participant's anthropometric parameters

\begin{tabular}{|c|c|c|c|c|c|c|}
\hline \multicolumn{3}{|c|}{ Variables } & Total & Women & Men & $\mathrm{p}$-value \\
\hline \multirow{4}{*}{\multicolumn{2}{|c|}{ Age (years) }} & Mean \pm SD & $22 \pm 6$ & $18 \pm 3$ & $25 \pm 6$ & \multirow[t]{4}{*}{$<0.0001^{*}$} \\
\hline & & $<20$ & $49(44.1)$ & $38(70.4)$ & $11(19.3)$ & \\
\hline & & $20-30$ & $47(42.3)$ & $15(27.8)$ & $32(56.1)$ & \\
\hline & & $\geq 30$ & $15(13.5)$ & $1(1.9)$ & $14(24.6)$ & \\
\hline \multirow{2}{*}{\multicolumn{2}{|c|}{ Profession }} & students & $96(86.5)$ & $54(100)$ & $42(73.7)$ & \multirow[t]{2}{*}{$<0.0001^{*}$} \\
\hline & & workers & $15(13.5)$ & 0 & $15(26.3)$ & \\
\hline \multirow{2}{*}{\multicolumn{2}{|c|}{ Category }} & Juniors & $32(28.8)$ & $23(42.6)$ & $9(15.8)$ & \multirow[t]{2}{*}{$0.004 *$} \\
\hline & & Seniors & $79(71.2)$ & $31(57.4)$ & $48(84.2)$ & \\
\hline \multirow[t]{6}{*}{ BMI } & BMI (before Semi-lockdown & Mean \pm SD & $22.7 \pm 3$ & $22.7 \pm 2.9$ & $22.7 \pm 3.2$ & 0.761 \\
\hline & BMI (After Semi-lockdown) & Mean \pm SD & $23.3 \pm 2.6$ & $23.4 \pm 2.8$ & $23.2 \pm 2.5$ & 0.711 \\
\hline & $\neq \mathrm{BMI}$ & Mean \pm SD & $0.6 \pm 1.6$ & $0.6 \pm 1.7$ & $0.5 \pm 1.6$ & 0.657 \\
\hline & \multirow[t]{3}{*}{$\Delta \mathrm{BMI}$} & Gain & $78(70.3)$ & $37(68.5)$ & $41(71.9)$ & \multirow[t]{3}{*}{0.657} \\
\hline & & Equal & $2(1.8)$ & $1(1.9)$ & $1(1.8)$ & \\
\hline & & Lost & $31(27.9)$ & $16(29.6)$ & $15(26.3)$ & \\
\hline
\end{tabular}

$\Delta$ Variation; $\neq$ Difference * Independent samples t-test 
Regarding the continuity of training, $82 \%$ of the volleyball players continued training during the semi-lockdown period against $18 \%$ who interrupted totally, without any significant gender-wise difference $(p=0.91)$ (Table 2$)$. Of the 91 volleyball players who continued training, $72.5 \%$ trained at home and $27.5 \%$ on a court, with more male players training than females $(\mathrm{p}=0.004)$. In addition, $68.1 \%$ did their training individually, $25.3 \%$ with teammates, and $6.6 \%$ with a coach, which showed a significant gender difference $(\mathrm{p}=0.011)$. Finally, out of 91 volleyball players, $6.6 \%$ trained due to coach recommendation, $18.7 \%$ to chase boredom away, and $74.7 \%$ by personal initiative, without any significant gender-wise difference $(\mathrm{p}=0.948)$.

Table 2. Comparison by gender of training continuity [ $\mathrm{n}=91$ ( 45 women and 46 men)]

\begin{tabular}{|l|l|l|l|l|l|}
\hline Variables & Total \% & Women \% & Men \% & p-value \\
\hline \multirow{2}{*}{ Where did the training take place? } & Home (alone) & 72.5 & 57.8 & 87 & $0.004^{*}$ \\
\cline { 2 - 5 } & Training ground (collective) & 27.5 & 42.2 & 13 & \\
\hline \multirow{3}{*}{ With who did you train? } & Alone & 68.1 & 53.3 & 82.6 & \multirow{2}{*}{$0.011^{*}$} \\
\cline { 2 - 5 } & With teammate & 25.3 & 37.8 & 13 & \\
\cline { 2 - 5 } & With coach (s) & 6.6 & 8.9 & 4.3 & \\
\hline \multirow{2}{*}{$\begin{array}{l}\text { What was the reason for your training } \\
\text { during the semi-lockdown period? }\end{array}$} & Coach recommendation & 6.6 & 6.7 & 6.5 & \multirow{2}{*}{0.948} \\
\cline { 2 - 5 } & Boredom & 18.7 & 20 & 17.4 & \\
\cline { 2 - 4 } & Self-motivation & 74.7 & 73.3 & 76.1 & \\
\hline
\end{tabular}

n: total participant; * Pearson Chi-square (goodness of fit test) [significant at level $\leq 0.05$.]

Concerning the effects of semi-lockdown on the number of sessions, Table 3 shows that out of a group of 30 volleyball players, $40 \%$ maintained, $26.7 \%$ reduced, and $33.3 \%$ increased the number of solo training sessions. This trend was the same in males and females $(\mathrm{p}=0.897)$. Of the 21 athletes who continued collective training among the 111 volleyball players, $23.8 \%$ maintained, $71.4 \%$ reduced, and $4.8 \%$ increased the number of collective training sessions, with the same behavior between males and females $(\mathrm{p}=0.301)$. Of a total of 17 volleyball players, $52.9 \%$ maintained, $29.4 \%$ reduced, and $17.6 \%$ increased the number of training sessions with their coach without genderwise difference in behavior $(\mathrm{p}=0.413)$.

Regarding the effects of semi-lockdown on the relationship with the coach and the scheduling of training sessions, out of 111 volleyball players, $37.8 \%$ were not in permanent contact, $13.5 \%$ were in contact at least once a day, $17.1 \%$ were in contact at least once every two days, and $31.5 \%$ were in contact at least once a week with the coach. No significant difference was observed between men and women $(\mathrm{p}=0.118)$. About $60.4 \%$ of 111 volleyball players had personalized training programs during the confinement period while $39.6 \%$ did not, with no significant gender differences observed ( $\mathrm{p}=0.087$ ). In addition, $52.3 \%$ indicated that they took precautions to address the lack of group training and $47.7 \%$ took no action. These measures were the same in both genders $(\mathrm{p}=0.212)$ (Table 3$)$. According to the effects of semi-lockdown on the type of training sessions, the results revealed that of the 100 volleyball players out of the $111,53 \%$ performed physical training, $5 \%$ performed technical training, and $42 \%$ performed both physical and technical training. There were no gender-wise differences in behavior $(\mathrm{p}=0.306)$ (Table 3). Of these 100 volleyball players, $65 \%$ preferred physical training, $13 \%$ technical training, and $22 \%$ both types of training (physical and technical). No significant gender difference was observed $(\mathrm{p}=0.872)$. Of a total of 99 among the 111 volleyball players, $21.2 \%$ performed aerobic training and $78.8 \%$ completed some other type of training. We noted no difference in the choice of training type in both genders $(\mathrm{p}=0.958)$.

Regarding the effects of semi-lockdown on physical performance (Table 3), of 109 out of 111 volleyball players, $43.1 \%$ thought the period of confinement led to diminishing strength capacity. This effect was the same in males and females $(\mathrm{p}=0.657)$. In addition, $55 \%$ of them thought that the confinement period resulted in a decrease in speed capacity, and no significant gender difference was noticed $(\mathrm{p}=0.9)$. Furthermore, $78 \%$ of the players thought the confinement period caused an endurance capacity decrease with no significant gender difference $(\mathrm{p}=0.397)$. At the end of the first training session in the presence of the coach, out of 82 volleyball players, the coach qualified the player's physical capacities as good $(18.3 \%)$, bad $(8.5 \%)$, and medium $(73.2 \%)$. The male players showed better physical capacities than females $(\mathrm{p}=0.005)$. 
Table 3. Effects of semi-lockdown on the number of sessions, Relationship with the coach and the scheduling of sessions, Type of session, and Physical performance

\begin{tabular}{|c|c|c|c|c|c|c|}
\hline \multicolumn{3}{|l|}{ Variables } & $\begin{array}{l}\text { Total } \\
\%\end{array}$ & $\begin{array}{l}\text { Women } \\
\%\end{array}$ & $\begin{array}{l}\text { Men } \\
\%\end{array}$ & p-value* \\
\hline \multirow[t]{9}{*}{ Number of sessions } & \multirow{3}{*}{$\begin{array}{l}\text { Variation of training sessions } \\
\text { alone }\end{array}$} & Equal & 40 & 50 & 38.5 & \multirow[t]{3}{*}{0.897} \\
\hline & & Less & 26.7 & 25 & 26.9 & \\
\hline & & Plus & 33.3 & 25 & 34.6 & \\
\hline & \multirow{3}{*}{$\begin{array}{l}\text { Variation of training sessions in } \\
\text { group }\end{array}$} & Equal & 23.8 & 14.3 & 42.9 & \multirow[t]{3}{*}{0.301} \\
\hline & & Less & 71.4 & 78.6 & 57.1 & \\
\hline & & Plus & 4.8 & 7.1 & 0 & \\
\hline & \multirow{3}{*}{$\begin{array}{l}\text { Variation of training sessions } \\
\text { with the coach }\end{array}$} & Equal & 52.9 & 40 & 71.4 & \multirow[t]{3}{*}{0.413} \\
\hline & & Less & 29.4 & 40 & 14.3 & \\
\hline & & Plus & 17.6 & 20 & 14.3 & \\
\hline \multirow{8}{*}{$\begin{array}{l}\text { Relationship with the } \\
\text { coach and the } \\
\text { scheduling of sessions }\end{array}$} & \multirow{4}{*}{$\begin{array}{l}\text { Were you in constant contact } \\
\text { with your head coach? }\end{array}$} & No & 37.8 & 35.2 & 40.4 & \multirow[t]{4}{*}{0.118} \\
\hline & & $\begin{array}{l}\text { At least once a } \\
\text { day }\end{array}$ & 13.5 & 11.1 & 15.8 & \\
\hline & & $\begin{array}{l}\text { At least once } \\
\text { every two } \\
\text { days }\end{array}$ & 17.1 & 25.9 & 8.8 & \\
\hline & & $\begin{array}{l}\text { At least once a } \\
\text { week }\end{array}$ & 31.5 & 27.8 & 35.1 & \\
\hline & \multirow{2}{*}{$\begin{array}{l}\text { Did you have any personalized } \\
\text { programs during the semi- } \\
\text { lockdown period? }\end{array}$} & Yes & 60.4 & 68.5 & 52.6 & \multirow[t]{2}{*}{0.087} \\
\hline & & No & 39.6 & 31.5 & 47.4 & \\
\hline & \multirow{2}{*}{$\begin{array}{l}\text { Had measures been taken to } \\
\text { compensate the lack of group } \\
\text { training? }\end{array}$} & Yes & 52.3 & 59.3 & 45.6 & \multirow[t]{2}{*}{0.212} \\
\hline & & No & 47.7 & 40.7 & 54.4 & \\
\hline \multirow[t]{8}{*}{ Type of session } & \multirow{3}{*}{$\begin{array}{l}\text { What type of training did you } \\
\text { completed during the semi- } \\
\text { lockdown period? }\end{array}$} & Physical & 53.0 & 58.0 & 48.0 & \multirow[t]{3}{*}{0.306} \\
\hline & & Technical & 5.0 & 2.0 & 8.0 & \\
\hline & & $\begin{array}{l}\text { Both } \\
\text { (technical and } \\
\text { physical) }\end{array}$ & 42.0 & 40.0 & 44.0 & \\
\hline & \multirow{3}{*}{$\begin{array}{l}\text { What type of training did you } \\
\text { prefer? }\end{array}$} & Physical & 65.0 & 64.0 & 66.0 & \multirow[t]{3}{*}{0.872} \\
\hline & & Technical & 13.0 & 12.0 & 14.0 & \\
\hline & & $\begin{array}{l}\text { Both } \\
\text { (technical and } \\
\text { physical) }\end{array}$ & 22.0 & 24.0 & 20.0 & \\
\hline & \multirow{2}{*}{$\begin{array}{l}\text { Did you complete aerobic } \\
\text { training sessions? }\end{array}$} & Yes & 21.2 & 20.0 & 22.4 & \multirow[t]{2}{*}{0.958} \\
\hline & & No & 78.8 & 80.0 & 77.6 & \\
\hline \multirow[t]{9}{*}{ Physical performance } & \multirow{2}{*}{$\begin{array}{l}\text { Do you think that the semi- } \\
\text { lockdown period resulted in a } \\
\text { decrease in your strength } \\
\text { capacity? }\end{array}$} & Yes & 43.1 & 45.3 & 41.1 & \multirow[t]{2}{*}{0.657} \\
\hline & & No & 56.9 & 54.7 & 58.9 & \\
\hline & \multirow{2}{*}{$\begin{array}{l}\text { Do you think the semi-lockdown } \\
\text { period caused a decrease in your } \\
\text { speed capacity? }\end{array}$} & Yes & 55 & 56.6 & 53.6 & \multirow[t]{2}{*}{0.9} \\
\hline & & No & 45 & 43.4 & 46.4 & \\
\hline & \multirow{2}{*}{$\begin{array}{l}\text { Do you think the semi-lockdown } \\
\text { period caused a decrease in your } \\
\text { endurance capacity? }\end{array}$} & Yes & 78 & 73.6 & 82.1 & 0.397 \\
\hline & & No & 22 & 26.4 & 17.9 & \\
\hline & What did the coach say about & Good & 18.3 & 6.7 & 32.4 & $0.005^{* *}$ \\
\hline & your physical abilities at the end & $\mathrm{Bad}$ & 8.5 & 13.3 & 2.7 & \\
\hline & of the first session together? & Average & 73.2 & 80 & 64.9 & \\
\hline
\end{tabular}

* Pearson Chi-square (goodness of fit test), ${ }^{* *}$ significant at level $\leq 0.01$ (the level of significance considered $\leq 0.05$ for the rest of examined hypotheses) 


\section{Discussion}

The results obtained in this research show that semi-confinement significantly affected the sporting and physical activity behavior of volleyball players, with women seemingly affected more than men. The semi-lockdown period did not induce anthropometric changes in volleyball players. Previous studies have shown that it takes a significant amount of time in physical activity to cause changes in weight status $(8,17,18)$. Moreover, the research participants were certified athletes and therefore, they had to maintain a certain level of physical activity during the restriction period, which favored the maintenance of body mass. This result is similar to that of Kaux and Francaux (2) who concluded in their study that physical activity carried out in moderation remains recommended for all and is beneficial during the Covid-19 pandemic, with some precautions to be taken. Furthermore, low-intensity training is recommended for recovery (19), and this is important during the Covid-19 pandemic to avoid a weakened immune system $(9,14,20-22)$. This result is contrary to that of Hughes et al. (13) who demonstrated that the preventive measures taken to limit the spread of Covid-19 have negatively affected a range of professional and social activities, including physical activities.

The volleyball players continued training during the semi-lockdown period. This result is similar to that obtained by Pillay et al. (14) among South African athletes who reported that more than half of the athletes exercised at a moderate intensity for 30-60 minutes per day. We also observed the same trend in Cameroonian basketball players where they maintained a certain level of training even though it was mostly done alone (15). The changes in quality of life and behavior observed in some cases as a result of the restrictions include a certain level of physical activity and exercise to maintain an adequate level of health (1). Indeed, the enacted government measures have banned collective training in clubs. To maintain a certain level of physical fitness, athletes had to continue physical activities individually at home. In relation to the continuity of training, male and female athletes behaved the same. This can be justified by the fact that despite the barrier measures, including travel restrictions, both male and female players continued to practice sports during the restriction period. We believe that the pandemic has not prevented volleyball players from continuing to practice sports on an individual basis, especially for athletes who believed in maintaining their performance. These results agree with those of previous studies $(15,14,23)$, showing that most athletes $(2 / 3)$ continued to train alone daily. Unfortunately, there is the risk of the eventual development of trauma (24).

The present study found that the volleyball players continued physical activity during semi-lockdown by simple personal motivation, meaning that the training carried out by these players was not supervised. As a result, this could cause physical and technical deficiencies $(14,24)$. Such changes can lead to impaired performance and an increased risk of injuries such as ruptured ligaments and muscle injuries (12) as the work performed during this period was not included in a specific volleyball program. This result is consistent with those of Aicale et al. (24) and Pillay et al. (14) who claim that inadvertent adoption of a poor technique and poor posture can predispose athletes to injury. For most athletes in general, individual training sessions increased and, group training sessions and training sessions with their trainer decreased. Indeed, the increase in the number of individual sessions, the decrease in the number of group sessions, and the stabilization of sessions with the trainer (52\%) during the restriction period are only normal. This could be justified in view of the measures enacted by the public authorities aimed to limit the gatherings of more than 50 people in public places, on the one hand, and the closure of structures approved for sports practice, on the other hand. It is in this sense that Hughes et al. (13) found that group training has been banned in sports clubs, forcing athletes, coaches, and managers to adopt new sports and managerial approaches. However, this situation could lead to technical shortcomings, as personal training and the absence of sport-specific training programs can be challenging for athletes who participate in highly technical and team sports $(14,19)$.

Regarding the relationship with the coach, to compensate for the lack of collective training, the coaches adopted virtual and remote methods to avoid any regrouping, following the prescriptions of health and government authorities. Other consequences of isolation are the lack of organization in training and competition, lack of communication between athletes and coaches, the inability to move freely, and inappropriate training conditions ( 5 , $25,26)$. The measures adopted by the coaches helped to avoid deconditioning in athletes facing a long period of potential inactivity. This possible deconditioning would have posed problems when resuming normal sports activities $(14,23)$. Contrary to the results of Pillay et al. (14) who showed that only a minority of athletes followed a digital guide offered by a professional, most players (60.4\%) used coach-designed training programs during the restriction period. These programs were established to maintain the physical capacities of athletes while awaiting a probable resumption of the national championships and to prevent athletes from adopting a fully sedentary lifestyle. Physical activities during the restriction period limited the risk of injury in the event of an abrupt resumption of competition $(12,14,23,27)$. Indeed, due to the lack of material for technical work and the reduction in group 
sessions, the players opted for physical work based on the program developed by their coach. Numerous studies have reported that, during the confinement period, the majority of athletes engaged in weight training, cardio training, and sport-specific functional training $(14,28,29)$.

Regarding the type of session performed during the restriction period, very few players performed aerobic exercises, because the weight training sessions offered by the coaches required them to perform explosive exercises. The fear of being infected with Covid-19 would have helped to reduce the number of aerobic sessions. Athletes, therefore, preferred to perform physical exercises $(78.8 \%)$, such as proprioception, which is easy to perform indoors, in confined spaces (14). Other studies have noted that only a small number of athletes have included proprioception in their programs $(14,26,28)$. Concerning physical performance, volleyball players experienced a decrease in strength, speed, and endurance capacities. This result seems normal since the restriction period led to a decrease in physical activity. Furthermore, due to the socio-economic status of our country, the players do not always have the necessary equipment for home training. Yet, during this period of restriction, players should have had full access to sports equipment such as treadmills, steppers, dumbbells, swimming pools, and stationary bikes, which provide plenty of opportunities for varied training $(14,26)$. Meanwhile, previous studies have shown that those not engaged in regular physical activity have a higher risk of functional decline (30). Once the government eased barriers, some volleyball players resumed group training and the coach qualified their physical capacities as being average. According to the results, the restriction period had a greater impact on women. Guessogo et al. (15) reported the same trend among Cameroonian basketball players.

\section{Strengths and limitations}

The present study is the first research on the activities of volleyball players in Cameroon during the Covid-19 restriction period intended to maintain their physical fitness. The semi-lockdown is similar to the inter-season in various championships. Coaches and sports managers must put in place strategies to limit inactivity during the cessation periods in order to promote a healthy and safe return to sport. One of the limitations of this study was access to accurate information such as weight before the pandemic, which had to be estimated by the athletes themselves. Furthermore, the cross-sectional approach may also limit the validity of the results.

\section{Conclusions}

Volleyball players adapted their physical activity behavior during the Covid-19 semi-lockdown, which had a significant physical effect on factors including body composition, the maintenance of physical activity and, the number and type of training sessions. Specific individualized programs are recommended to reduce the effects of semi-lockdown on physical capacity and promote a safe return to sport. Future studies can undertake the evaluation of the effects of semi-lockdown on the mental health of Cameroonian athletes.

\section{Acknowledgments:}

This study is a part of research work conducted in the National Institute of Youth and Sports of Yaounde, for the Physical Education and Sport Teacher Certificate. No fund or budget was assigned to this study. The authors thank all the volleyball players who participated in this study, as well as their coaches for the information they provided. We are also grateful to the staff of the Cameroonian Basketball Federation who provided the contact details of the players during the lockdown period.

\section{Conflict of Interest:}

There is no conflict of interest to be declared.

Authors' contributions:

All authors contributed to this project and article equally. All authors read and approved the final manuscript.

\section{References:}

1) Jiménez-Pavon D, Carbonell-Baeza A, Lavie CJ. Physical exercise as therapy to find against the mental and physical consequences of COVID-19 quarantine: Special focus in older people. Prog Cardiovasc Dis. 2020. doi: 10.1016/j.pcad.2020.03.009. PMid: 32220590, PMCid: PMC7118448

2) Kaux JF, Francaux M. L'activité physique en période de pandémie Covid-19. Sci Sports. 2020;35:117-118. doi: 10.1016/j.scispo.2020.05.001. PMid: 32454558, PMCid: PMC7232074 
3) $\mathrm{Wu} Z$, McGoogan JM. Characteristics of an important lessons from the coronavirus disease 2019 (COVID19) outbreak in china: summary of a report of 72,314 cases from the Chinese center for disease control and prevention. JAMA. 2020. https://dx.doi.org/10.1001/jama.2020.2648. PMid: 32091533

4) Pinto AJ, Dunstan DW, Owan N, Bonfa E, Gualano B. Combating physical inactivity during the Covid-19 pandemic. Nat Rev Rheumatol. 2020;16:347-348. doi: 10.1003/s41584-020-0427-z. PMid: 32355296m, PMCid: PMC7191971

5) Chen P, Mao L, Nassis GP, Harmer P, Ainsworth BE, Li F. Coronavirus disease (COVID-19): The need to maintain regular physical activity while taking precautions. J Sport Health Sci. 2020;9:103-4.doi: 10.1016/j.jshs.2020.02.001, PMid: 32099716, PMCid: PMC7031771

6) Zambrano-Monserrate MA, Ruano MA, Sanchez-Alcalde L. Indirects effects of COVID-19 on the environment. Sci Total Environ. 2020. doi: 10.1016/j.scitotenv.2020.138813. PMid: 32334159, PMCid: PMC7169883

7) Carvalho VO, Gois CO. COVID-19 pandemic and home-based physical activity. Immunol. 2020. doi: 10.1016/j.jaip.2020.05.018. PMid: 32470443, PMCid: PMC7250754

8) Peçanha T, Goessler KF, Roschel H, Gualano B. Social isolation during the COVID-19 pandemic can increase physical inactivity and the global burden of cardiovascular disease. Am J Physiol Heart Circ Physiol. 2020;318:H1441-H1446. doi:10.1152/ajpheart.00268.2020. PMid: 32412779, PMCid: PMC7303725

9) Hall G, Laddu DR, Phillips SA, Lavie CJ, Arena R. A tale of two pandemics: How will COVID-19 and global trends in physical inactivity and sedentary behavior affect one another? Prog Cardiovasc Dis. 2020. doi: 10.1016/j.pcad.2020.04.005. PMid: 32277997, PMCid: PMC7194897

10) Jurak G, Morrinon SA, Leskosek B, Kovac M, Hadzic V, Vodicar J, et al. Physical activity recommandations during the coronavirus disease-2019 virus outbreak. J Sport Health Sci. 2020. doi: 10.1016/j.jshs.2020.05.003. PMid: 32426171, PMCid: PMC7229466

11) Laddu DR, Lavie CJ, Phyllips SA, Arena R. Physical activity for immunity protection: Inoculating populations with healthy living medicine in preparation for the next pandemic. Prog Cardiovasc Dis. 2020. doi: 10.1016/j.pcad.2020.04.006. PMid: 32278694, PMCid: PMC7195025

12) Sarto F, Impellizzeri FM, Sporri J, Porcelli S, Olmo J, Requena B, et al. Impact of potential physiological changes due to COVID-19 home confinement on athlete health protection in elite sports: a call for awareness in sports programming. Int J Sports Med. 2020. doi: 10.1007/s40279-020-01297-6. PMid: 32468329, PMCid PMC7254973

13) Hughes D, Saw R, Perera NKP, Mooney M, Wallett A, Cooke J, et al. The Australian institute of sport framework for rebooting sport in a COVID-19 environment. J Sci Med Sport. 2020. doi: 10.1016/j.jsams.2020.05.004. PMid: 32451268, PMCid: PMC7200343

14) Pillay L, Rensburg DCCJV, Rensburrg AJV, Ramagole DA, Holtzhausen L, Dijkstra HP, Cronje T. Nowhere the hide: The significant impact of coronavirus disease 2019 (COVID-19) measures on elite and semi-elite South African athletes. J Sci Med Sport. 2020;23(7):670-679. doi: 10.1016/j.jsams.2020.05.016. PMid: 32448749, PMCid: PMC7235602

15) Guessogo WR, Bika Lele CB, Assomo Ndemba PB, Mekoulou Ndongo J, Hamadou A, Mban Bian W, et al. A Cross Sectional Study of the Cameroonian Elite Basketball Players towards their Physical Activity Attitudes Due to the Covid-19 Pandemic. Ann Physiother Occup Ther. 2020;3(3):000173.

16) Thomas S, Reading J, Shephard RJ. Revision of the physical activity readiness questionnaire (PAR-Q). Can J Sport Sci. 1992;17(4):338-345.

17) Krogh-Madsen R, Thilfaut JP, Broholm C, Mortensen OH, Olsen RH, Mounier R, et al. A 2 w-k reduction of ambulatory activity attenuates peripheral insulin sensitivity. J Appl Physiol. 2010;108:1034-1040. PMid: 20044474

18) Martinez-Ferran M, de la Guia-Galipienso F, Sanchis-Gomar F, Pareja-Galeano H. Metabolic impacts of confinement during the COVID-19 pandemic due to modified diet and physical activity habits. Nutrients. 2020;12:1549. doi: 10.3390/nu12061549. PMid: 32466598, PMCid: PMC7352228

19) Maupin D, Schram B, Canetti E, Orr R. The relationship between acute: chronic workload ratios and injury risk in sports: a systematic review. Open Access J Sports Med. 2020;11:51. PMid: 32158285, PMCid: PMC7047972

20) Matthews CE, Ockene IS, Freedson PS, Rosal MC, Merriam PA, Hebert JR. Moderate to vigorous physical activity and risk of upper-respiratory tract infection. Med Sci Sports Exerc. 2002;34(8):1242-1248.doi: 10.1097/00005768-200208000-00003, PMid: 12165677 
21) Soligard T, Steffen K, Palmer D, Alonso JM, Bahr R, Lopes AD, et al. Sports injury and illness incidence in the Rio de Janeiro 2016 Olympic summer games: a prospective study of 11,274 athletes from 207 countries. Br J Sports Med. 2017;51:1265-1271. doi: 10.1136/bjsports-2017-097956, PMid: 28756389

22) Schwellnus M, Soligard T, Alonso JM, Bahr R, Clarsen B, Dijkstra HP, et al. How much is too much? (Part 2) international Olympic Committee consensus statement on load in sport and risk of illness. Br J Sports Med. 2016;50(17):1043-1052. doi: 10.1136/bjsports-2016-096572, PMid: 27535991. PMCid: PMC5013087

23) Myer GD, Faigenbaum AD, Cherny CE, Heidt Jr RS, Hewett TE. Did the NFL lockout expose the Achilles heel of competitives sports? J Orthop Sports Phys Ther. 2011;41(10):702-705. doi: 10.2519/jospt.2011.0107. PMid: 21941038

24) Aicale R, Tarantino D, Maffuli N. Overuse injuries in sport: a comprehensive overview. J Orthop Surg Res. 2018;13(1):1-11. doi: 10.1186/s13018-018-1017-5, PMid: 30518382, PMCid: PMC6282309

25) Hemphil NM, Kuan MTY, Harris KC. Reduced physical activity during COVID-19 pandemic in children with congenital heart disease. Can J Cardiol. 2020. doi: 10.1016/j.cjca.2020.04.038. PMid: 32387502, PMCid: PMC7199682

26) Jukic I, Calleja-González J, Cos F, Cuzzolin F, Olmo J, Terrados N, et al. Strategies and solutions for team sports athletes in isolation due to COVID-19. Multidisciplinary Digital Publishing Institute. 2020. doi: 10.3390/sports8040056, PMid: 32344657, PMCid: PMC7240607

27) Mujika I, Padilla S. Muscular characteristic of detraining of humans. Med Sci Sports Exerc. 2001;33(8):1297-303. doi: 10.1097/00005768-200108000-00009, PMid: 11474330

28) Ogard WK. Proprioceptions in Sports medicine and athletics conditionning. Strength J Cond. 2011;33(3):111-118. https://dx.doi.org/10.1519/SSC.0b013e31821f3ae.

29) de Oliveira Neto L, Elsangedy HM, de Oliveira Tavares VD, Teixeira CVLS, Behm DG, Silva-Grigoletto MED. Training in home-based training during COVID-19 (SARS-COV2) pandemic: physical exercise and behaviour-based approch. Rev Bra Fisiol Exerc. 2020;19(2):S9-S19. doi: 10.33233/rbfe.v19i2.4006

30) Goethals L, Barth N, Guyot J, Hupin D, Celarier T, Bongue B. Impact of home quarantine on physical activities among older adults living at home during the COVID-19 pandemic: Qualitative Interview Study. JMIR Aging. 2020;3(1):e19007. doi: 10.2196/19007. PMid: 32356777, PMCid: PMC7207013 